\title{
Chloroplast pigments and photochemical efficiency of West Indian cherry under salt stress and potassium- phosphorus fertilization
}

\section{Pigmentos cloroplastídicos e eficiência fotoquímica da aceroleira sob estresse salino e adubação com potássio-fósforo}

Adaan Sudario Dias ${ }^{1 *} ;$ Geovani Soares de Lima²; Hans Raj Gheyii; Guilherme de Freitas Furtado ${ }^{3}$; Lauriane Almeida dos Anjos Soares ${ }^{4}$; Reginaldo Gomes Nobre ${ }^{5}$; Rômulo Carantino Lucena Moreira'; Pedro Dantas Fernandes²

\section{Highlights}

Photosynthetic apparatus integrity is compromised by salt stress.

Irrigation water salinity negatively affects chlorophyll a fluorescence signals.

Potassium-phosphorus supply attenuates salt stress on chlorophyll $a$ and $b$ contents.

\begin{abstract}
The objective of this study was to evaluate chloroplast pigments and photochemical efficiency of West Indian cherry cv. BRS 366 Jaburu as a function of irrigation water salinity and potassium-phosphorus fertilization combinations in the second year of cultivation. The experiment was carried out in a protected environment in Campina Grande, Brazil. Treatments were distributed in randomized blocks, in a $5 \times 4$ factorial scheme, corresponding to five levels of electrical conductivity of irrigation water $\mathrm{ECw}(0.6,1.4,2.2,3.0$ and $\left.3.8 \mathrm{dS} \mathrm{m}^{-1}\right)$ and four combinations of potassium-phosphorus fertilization (100/100, 85/85, 60/60 and 45/45\% of the $\mathrm{K}_{2} \mathrm{O}_{2} \mathrm{P}_{2} \mathrm{O}_{5}$ recommendation for the second year of cultivation $200 \mathrm{~g}$ of $\mathrm{K}_{2} \mathrm{O}$ and $120 \mathrm{~g}$ of $\mathrm{P}_{2} \mathrm{O}_{5}$ per plant per year) with three replicates. Irrigation with saline waters hampered the biosynthesis of chloroplast pigments and the photochemical efficiency of West Indian cherry cv. BRS 366 Jaburu in the second year of

1 Discentes do Curso de Doutorado do Programa de Pós-Graduação em Engenharia Agrícola, Universidade Federal de Campina Grande, UFCG, Centro de Tecnologia e Recursos Naturais, Campina Grande, PB, Brasil. E-mail: adaansudariodias@gmail.com; romulocarantino@gmail.com

2 Profs., Programa de Pós-Graduação em Engenharia Agrícola, Centro de Tecnologia e Recursos Naturais, UFCG, Campina Grande, PB, Brasil. E-mail: geovanisoareslima@gmail.com; hans@pq.cnpq.br; pedrodantasfernandes@ gmail.com

${ }^{3}$ Extensionist, Serviço Nacional de Aprendizagem Rural, João Pessoa, PB, Brasil. E-mail: gfreitasagro@gmail.com

${ }^{4}$ Profa, Unidade Acadêmica de Ciências Agrárias, UFCG, Pombal, PB, Brasil. E-mail: lauriane.soares@pq.cnpq.br

5 Prof., Departamento de Ciências e Tecnologia, Universidade Federal Rural do Semi-Árido, UFERSA, Caraúbas, RN, Brasil. E-mail: rgomesnobre@yahoo.com.br

* Author for correspondence
\end{abstract}

Received: Apr. 27, 2020 - Approved: Oct. 20, 2020 
cultivation. Water salinity from $2.6 \mathrm{dS} \mathrm{m}^{-1}$ reduced the maximum fluorescence, variable fluorescence, and quantum efficiency of photosystem II of West Indian cherry plants cv. BRS 366 Jaburu. Fertilization with $60 / 60$ and $85 / 85 \%$ of the $\mathrm{K}_{2} \mathrm{O} / \mathrm{P}_{2} \mathrm{O}_{5}$ recommendation promotes an increase in the synthesis of chlorophylls $a$ and $b$, respectively, in the first and second production cycles of the second year of cultivation. Supply of $85 / 85 \%$ of the $\mathrm{K}_{2} \mathrm{O}_{2} \mathrm{P}_{2} \mathrm{O}_{5}$ recommendation promoted an increase in maximum and variable fluorescence in plants subjected to water salinities of $0.6,2.2$, and $3.8 \mathrm{dS} \mathrm{m}^{-1}$ in the second cycle and reduced the initial fluorescence, regardless of the salinity level in the first and second production cycles of West Indian cherry. Key words: Malpighia emarginata Sesse \& Moc. ex DC. Salt stress. Chlorophyll. Fluorescence.

\section{Resumo}

Objetivou-se com esta pesquisa avaliar os pigmentos cloroplastídicos e a eficiência fotoquímica da aceroleira cv. BRS 366 Jaburu em função da salinidade da água de irrigação e combinações de adubação com potássio-fósforo no segundo ano de cultivo. A pesquisa foi realizada em ambiente protegido, em Campina Grande-PB. Os tratamentos foram distribuídos em blocos casualizados, em esquema fatorial $5 \times 4$, sendo cinco níveis de condutividade elétrica da água de irrigação - CEa $(0,6 ; 1,4 ; 2,2 ; 3,0$ e 3,8 dS $\mathrm{m}^{-1}$ ), e quatro combinações de adubação com potássio-fósforo (100/100; 85/85; 60/60 e 45/45\% de $\mathrm{K}_{2} \mathrm{O}$ / $\mathrm{P}_{2} \mathrm{O}_{5}$, da recomendação para o segundo ano de cultivo) com três repetições. A combinação de 100/100\% correspondeu a $200 \mathrm{~g}$ de $\mathrm{K}_{2} \mathrm{O}$ e $120 \mathrm{~g}$ de $\mathrm{P}_{2} \mathrm{O}_{5}$ por planta por ano). A irrigação com águas salinas prejudicou a biossíntese de pigmentos cloroplastídicos e a eficiência fotoquímica da aceroleira cv. BRS 366 Jaburu no segundo ano de cultivo. A salinidade da água a partir de 2,6 dS m-1 diminuiu a fluorescência máxima, variável e eficiência quântica do fotossistema II das plantas de aceroleira cv. BRS 366 Jaburu. A adubação com $60 / 60$ e 85/85\% da recomendação de $\mathrm{K}_{2} \mathrm{O}_{2} \mathrm{P}_{2} \mathrm{O}_{5}$ promovem aumento na síntese de clorofila $a$ e $b$ de acerola, respectivamente, no primeiro e segundo ciclos produtivos do segundo ano de cultivo. $\mathrm{O}$ fornecimento de $85 / 85 \%$ da recomendação de $\mathrm{K}_{2} \mathrm{O} / \mathrm{P}_{2} \mathrm{O}_{5}$ promoveu aumento na florescência máxima e variável nas plantas submetidas a salinidade da água de 0,$6 ; 2,2$ e 3,8 dS $\mathrm{m}^{-1}$ no segundo ciclo e reduziu a fluorescência inicial independentemente do nível salino no primeiro e segundo ciclo produtivo da acerola.

Palavras-chave: Malpighia emarginata Sesse \& Moc. ex DC. Estresse salino. Clorofila. Fluorescência.

\section{Introduction}

West Indian cherry (Malpighia emarginata Sesse \& Moc. ex DC.) has stood out in Brazil as a promising fruit crop for agribusiness, due to the high contents of vitamin $\mathrm{C}$, anthocyanins, and carotenoids in its fruits (Dias, Lima, Pinheiro, Gheyi, \& Soares, 2019; Sá et al., 2019a) and for being a tropical crop that has found favorable edaphoclimatic conditions for its cultivation in the Northeast region (E. M. Silva, Gheyi, Nobre, Barbosa, \& Souza, 2019), which is the main producing region and is responsible for $70 \%$ of the national production (Furlaneto \& Nasser, 2015).

Water availability in semi-arid areas of Northeastern Brazil is limited, especially in periods of higher atmospheric demand that coincide with periods of low rainfall. In areas where annual rainfall is less than $1,000 \mathrm{~mm}$, West Indian cherry fruits grow small, wrinkled and with low vitamin $\mathrm{C}$ content, so rainfall levels 
between 1,200 and 1,600 $\mathrm{mm}$, well distributed throughout the year, are required so that West Indian cherry has an optimal development and production of quality fruits (Calgaro \& Braga, 2012).

As the semi-arid region of Northeastern Brazil has an irregularly distributed rainfall regime in space and time, with precipitation around $800 \mathrm{~mm}$, an average temperature of $27{ }^{\circ} \mathrm{C}$ and potential evapotranspiration of $2,000 \mathrm{~mm}$ per year, resulting in negative water balance in most of the year (Guimarães et al., 2016), irrigation must be considered as an indispensable practice to ensure agricultural production. However, in this region, the waters available for irrigation commonly have high levels of salts. According to Sá et al. (2019b), the use of saline water in irrigation is a promising alternative to meet the deficient water demand.

The use of waters with high concentrations of salts can promote changes in the synthesis of photosynthetic pigments and the photochemical efficiency of plants. Thus, the search for alternatives capable of alleviating the effects of salt stress on plants is of fundamental importance to ensure the expansion of irrigated areas.

The exposure of plants to irrigation with saline waters hampers physiological, biochemical, and molecular processes (A. R. A. Silva, Bezerra, Lacerda, Sousa, \& Chagas, 2016) as a result of increased generation of reactive oxygen species (ROS), which damage cellular components and cause chlorophyll degradation and lipid peroxidation of the membrane, thus reducing membrane fluidity and selectivity (Taibi et al., 2016).

Therefore, the use of saline water in agriculture is conditioned on the management practices adopted to minimize its negative effects. In this context, Andrade, Pereira, Fernandes, Queiroga and Queiroga (2011) and Silva et al. (2019) point out that an increase in the supply of certain nutrients, such as $\mathrm{K}$ and $\mathrm{P}$, reduces the absorption of $\mathrm{Na}^{+}$and $\mathrm{Cl}^{-}$ions through competitive inhibition, promoting increased tolerance of the crop to salinity. Heidari and Jamshid (2010) and Prazeres et al. (2015) state that $\mathrm{K}$ contributes to enzymatic activation, respiration, photosynthesis, and improvement in water balance. According to Diniz et al. (2018), phosphorus acts in energy storage, root development, water use efficiency, and absorption, and the use of nutrients such as nitrogen due to the synergism among them.

Although the beneficial effects of the isolated actions of these nutrients on plants are known, studies evaluating their combined action, especially under water salinity conditions, are still incipient. Given the above, the objective of this study was to evaluate the chloroplast pigments and photochemical efficiency of West Indian cherry cv. BRS 366 Jaburu was cultivated under increasing levels of irrigation water salinity and fertilization with potassium-phosphorus combinations in the second year of cultivation.

\section{Material and Methods}

The study was carried out from January to December 2019 under greenhouse conditions, at the Center for Technology and Natural Resources of the Federal University of Campina Grande (CTRN/UFCG), located in the municipality of Campina Grande, Paraíba, Brazil, located at the geographic coordinates $7^{\circ} 15^{\prime} 18^{\prime \prime} \mathrm{S}$ latitude, 35 52' 28" W longitude with an altitude of $550 \mathrm{~m}$. 
Plastic pots with capacity of $250 \mathrm{~L}$, adapted as drainage lysimeters, were filled with a 1-kg layer of crushed $N^{\circ} 0$ stone, followed by $250 \mathrm{~kg}$ of a Psamment with sandy loam texture, with the following chemical and physical characteristics obtained according to Teixeira, Donagema, Fontana and Teixeira (2017): $\mathrm{Ca}^{2+}$ $=3.49 \mathrm{cmol}_{\mathrm{c}} \mathrm{kg}^{-1}, \mathrm{Mg}^{2+}=2.99 \mathrm{cmol}_{\mathrm{c}} \mathrm{kg}^{-1}, \mathrm{P}=$ $18.20 \mathrm{mg} \mathrm{kg}^{-1}, \mathrm{Na}^{+}=0.17 \mathrm{cmol}_{\mathrm{c}} \mathrm{kg}^{-1}, \mathrm{~K}^{+}=0.21$ $\mathrm{cmol}_{\mathrm{c}} \mathrm{kg}^{-1}, \mathrm{H}^{+}+\mathrm{Al}^{3+}=5.81 \mathrm{cmol}_{\mathrm{c}} \mathrm{kg}^{-1}$, organic

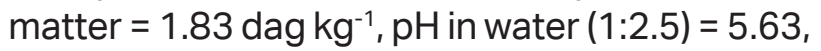
electrical conductivity of saturation extract $=$ $0.61 \mathrm{dS} \mathrm{m}^{-1}$, exchangeable sodium percentage $=2.48 \%$, sand $=573 \mathrm{~g} \mathrm{~kg}^{-1}$, silt $=101 \mathrm{~g} \mathrm{~kg}^{-1}$, clay $=326 \mathrm{~g} \mathrm{~kg}^{-1}$, moisture at $33.42 \mathrm{kPa}=12.68 \mathrm{dag}$

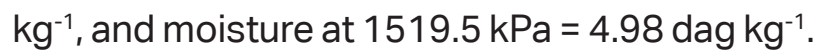

This study consisted of growing West Indian cherry in the second year of cultivation, continuing a previous study that evaluated five levels of electrical conductivity of irrigation water-ECw $\left(0.6,1.4,2.2,3.0\right.$, and $\left.3.8 \mathrm{dS} \mathrm{m}^{-1}\right)$ and four combinations of nitrogen-phosphorus$\mathrm{P} / \mathrm{N}$ fertilization (100:100, 140:100, 100:140 and $140: 140 \%$ of $\mathrm{P} / \mathrm{N}$ recommendation) distributed in randomized blocks with three replicates. The 100/100\% combination of $N$ and $\mathrm{P}_{2} \mathrm{O}_{5}$ corresponded to 23.85 and $45 \mathrm{~g}$ per plant per year, as recommended by Musser (1955) for the West Indian cherry crop. It is worth pointing out that the effects of irrigation water salinity and proportions of phosphorus and nitrogen on the growth and physiological, nutritional, and production aspects of West Indian cherry cv. BRS 366 Jaburu, grafted on an heirloom variety, were evaluated in the first cycle of cultivation (from transplanting to 350 days).

The second year of cultivation was also divided into two production cycles with 6 months of duration each. After the harvest of the first cycle, corrective pruning was performed to eliminate unwanted as well as poorly positioned branches, maintaining a canopy height of $1.5 \mathrm{~m}$, which was standardized to facilitate harvesting operations, aeration, light entry, and pest control (Calgaro \& Braga, 2012).

The treatments were distributed in randomized blocks, using a $5 \times 4$ factorial arrangeme nt, which corresponded to five levels of electrical conductivity of irrigation water-ECw $(0.6,1.4,2.2,3.0$ and 3.8 dS $\mathrm{m}^{-1}$ ) and four combinations of potassiumphosphorus fertilization - FC (100:100, 85:85, $60: 60$ and $45: 45 \%$ of the recommendation for the crop in the second year of cultivation), with three replicates and one plant per plot, totaling 60 experimental units. The dose of $100 \%$ of $\mathrm{K}_{2} \mathrm{O}$ and $\mathrm{P}_{2} \mathrm{O}_{5}$ corresponded to 200 and 120 $g$ per plant per year, respectively (Cavalcanti, 2008). To meet the $\mathrm{N}$ recommendation, 200 $\mathrm{g}$ per plant were applied as recommended by Cavalcanti (2008) for the cultivation of West Indian cherry in the second year of production. In the first cultivation cycle, the recommendation of Musser (1955) was used, and the NPK values indicated for West Indian cherry did not mitigate the deleterious effect of salt stress on the crop. Thus, for the second cycle of cultivation, it was decided to use higher doses of NPK, as indicated by Cavalcanti (2008), for the cultivation of West Indian cherry in the second year.

Fertilization with $\mathrm{N}, \mathrm{P}$, and $\mathrm{K}$ was performed using mono ammonium phosphate - MAP $\left(11 \% \mathrm{~N}\right.$ and $\left.60 \% \mathrm{P}_{2} \mathrm{O}_{5}\right)$ as a source of phosphorus and nitrogen, urea $(45 \% \mathrm{~N})$ as a complementary source of nitrogen, and potassium chloride $\left(60 \% \mathrm{~K}_{2} \mathrm{O}\right)$ as a source of potassium. Phosphate fertilization was split into 12 equal portions, applied as top-dressing in the first week of each month, while potassium 
and nitrogen fertilization was supplied in the second, third, and fourth weeks of each month, i.e., 3 times a month, totaling 36 equal applications of both $\mathrm{N}$ and $\mathrm{K}_{2} \mathrm{O}$; in addition, fertilization was performed every fortnight with spray on the adaxial and abaxial sides of leaves with micronutrients at a concentration of $0.5 \mathrm{~g}$ $\mathrm{L}^{-1}$ using as source the foliar fertilizer Quimifol Nutri, which has $25 \%$ potassium $\left(\mathrm{K}_{2} \mathrm{O}\right), 2.5 \%$ magnesium, $6.0 \%$ sulfur, $2.0 \%$ boron, $0.5 \%$ copper, $0.3 \%$ molybdenum and $5.0 \%$ zinc.

The levels of irrigation water salinity were prepared by dissolving the salts $\mathrm{NaCl}$, $\mathrm{CaCl}_{2} \cdot 2 \mathrm{H}_{2} \mathrm{O}$ and $\mathrm{MgCl}_{2} \cdot 6 \mathrm{H}_{2} \mathrm{O}$, in the equivalent proportion of 7:2:1 in municipal supply water $\left(E C w=0.4 \mathrm{dS} \mathrm{m}^{-1}\right)$ from Campina Grande, PB. Irrigations with the different ECw levels were carried out while adopting a 2-day irrigation interval, applying in each lysimeter a volume of water to maintain soil moisture close to the maximum retention capacity. The volume of water applied was obtained by the difference between the volume applied and the volume drained in the previous irrigation. Every 30 days, a leaching fraction of 0.10 was applied to avoid excessive accumulation of salts in the root zone.

Chloroplast pigments and chlorophyll a fluorescence were determined in the stage of full flowering/fruiting in March and September 2019 (second year of cultivation). The determinations were performed using the previously identified quaternary branches of the plants to ensure that they would be obtained from branches of same age and vigor. To determine chloroplast pigments, leaf samples were collected from 06:00 to 07:00 a.m. After collection, the samples were immediately sent to the laboratory for the removal of 5 leaf discs, which were weighed and then immersed in $40 \mathrm{~mL}$ of acetone (80\%) and kept in a refrigerator for 48 hours. After this period, the extracts obtained were evaluated by spectrophotometer at absorbance wavelength (ABS 470, 646, and $663 \mathrm{~nm}$ ) using Eqs. 1, 2, and 3 to estimate the contents of chlorophyll $a$, chlorophyll $b$, and carotenoids, respectively, according to the methodology recommended by Arnon (1949), whose results were presented in $\mathrm{mg} \mathrm{g}^{-1}$ of fresh matter (FM).

$$
\begin{array}{ll}
\text { Chlorophyll } a(\mathrm{Chl})=\left(12.21 \times \mathrm{ABS}_{663}\right)-\left(2.81 \times \mathrm{ABS}_{646}\right) & \text { Eq. } 1 \\
\text { Chlorophyll } b(\mathrm{Chl} b)=\left(20.13 \times \mathrm{ABS}_{646}\right)-\left(5.03 \times \mathrm{ABS}_{663}\right) & \text { Eq. } 2 \\
\text { Carotenoids }(\mathrm{Car})=\left[\left(1000 \times \mathrm{ABS}_{470}\right)-(1.82 \mathrm{Cl} \mathrm{a}-85.02 \mathrm{Cl} b)\right] / 198 & \text { Eq. } 3
\end{array}
$$

Chlorophyll a fluorescence [initial fluorescence (Fo), maximum fluorescence (Fm), variable fluorescence (Fm-Fo) and quantum efficiency of photosystem II (Fv/Fm)] was measured in leaves pre-adapted to the dark using leaf clips for 30 minutes, between 06:00 and 08:00 a.m. using a pulse-modulated fluorometer Plant Efficiency Analyzer PEA II .
The data obtained were subjected to analysis of variance by the $F$ test. When significant, polygonal regression analysis was performed for the water salinity factor, and the means comparison test (Tukey at 0.05 probability level) was performed for potassiumphosphorus combinations, using the statistical program SISVAR 4.2 (Ferreira, 2011). The 
regression model was chosen considering the value of $\mathrm{R}^{2}$ and the ability to explain the biological phenomena.

\section{Results and Discussion}

According to the $\mathrm{F}$ test results (Table 1), water salinity significantly influenced chlorophyll $a$ and $b$ contents and the initial fluorescence and variable fluorescence of West Indian cherry plants in the two production cycles, while carotenoid contents, maximum fluorescence, and quantum efficiency of PSII (Fv/Fm) were significantly influenced only in the first production cycle. The potassiumphosphorus fertilization combinations factor caused a significant effect on the maximum fluorescence and variable fluorescence in the second production cycle. However, chlorophyll $a(C h / a)$ and chlorophyll $b(C h / b)$ contents as well as Fo were influenced in both production cycles. The interaction between factors (SL $x$ $\mathrm{FC}$ ) significantly influenced Fv and Fm only in the second cultivation cycle and the $\mathrm{Chl}$ a and $C h l b$ contents and Fo of West Indian cherry plants in the two production cycles of the second year of cultivation.

Second production cycle $(A)$ and the second (B) production cycles

Fertilization with $60 / 60 \%$ of the $\mathrm{K}_{2} \mathrm{O}$ / $\mathrm{P}_{2} \mathrm{O}_{5}$ recommendation stimulated chlorophyll a synthesis by plants irrigated using water with ECw of 0.6 and $3.0 \mathrm{dS} \mathrm{m} \mathrm{m}^{-1}$, which had the highest values (1.632 and $0.934 \mathrm{mg} \mathrm{g}^{-1}$ of FM, respectively). Plants grown with $1.4 \mathrm{dS} \mathrm{m}^{-1}$ water obtained the highest value (1.010 $\mathrm{mg} \mathrm{g}^{-1} \mathrm{FM}$ ) of chlorophyll a when fertilized with the $\mathrm{K}_{2} \mathrm{O}_{2} \mathrm{P}_{2} \mathrm{O}_{5}$ combination of $85 / 85 \%$, differing statistically from those fertilized with $60 / 60 \%$ and $45 / 45 \%$. There was no significant difference between the combinations of fertilization in plants irrigated with waters of 2.2 and $3.8 \mathrm{dS} \mathrm{m}^{-1}$ in the first production cycle (Figure 1A).

In the second production cycle, the means comparison test (Figure 1B) showed a statistical difference for the $\mathrm{Chl}$ a content of the West Indian cherry between the potassium/ phosphorus combinations at all salinity levels. The supply of potassium/phosphorus in the combination of $85 / 85 \%$ of the $\mathrm{K}_{2} \mathrm{O}_{2} \mathrm{P}_{2} \mathrm{O}_{5}$ recommendation led to the highest contents of $\mathrm{Chl}$ a $\left(0.893 ; 0.971\right.$ and $0.624 \mathrm{mg} \mathrm{g}^{-1} \mathrm{FM}$ in plants irrigated with ECw of $0.6,1.4$, and $2.2 \mathrm{dS}$ $\mathrm{m}^{-1}$, respectively), differing from combinations 100/100, 60/60 and 45/45\%. In plants grown under ECw of 3.0 and $3.8 \mathrm{dS} \mathrm{m}^{-1}$, the highest contents of $\mathrm{Chl}$ a were obtained when using the combination of $45 / 45 \%$ of the $\mathrm{K}_{2} \mathrm{O}_{2} \mathrm{P}_{2} \mathrm{O}_{5}$ recommendation. However, chlorophyll a contents in plants irrigated with $3.0 \mathrm{dS} \mathrm{m}^{-1}$ water and fertilized with $45 / 45 \%$ of $\mathrm{K}_{2} \mathrm{O}_{2} \mathrm{P}_{2} \mathrm{O}_{5}$ did not differ statistically from those under $100 / 100 \%$ of $\mathrm{K}_{2} \mathrm{O} / \mathrm{P}_{2} \mathrm{O}_{5}$; on the other hand, in West Indian cherry plants grown under the highest salinity level $\left(3.8 \mathrm{dS} \mathrm{m}^{-1}\right)$, the combination of $45 / 45 \%$ $\mathrm{K}_{2} \mathrm{O} / \mathrm{P}_{2} \mathrm{O}_{5}$ significantly differed from the other combinations (Figure 1B). 
Table 1

Summary of the $\mathrm{F}$ test for the contents of chlorophyll $a(\mathrm{Chl} a)$, chlorophyll $\boldsymbol{b}(\mathrm{Chl} b)$ carotenoids (Car), initial fluorescence (Fo), maximum fluorescence (Fm), variable fluorescence (Fv), and quantum efficiency of PSII (Fv/Fm) of West Indian cherry plants cv. BRS 366 Jaburu irrigated with saline water and fertilized with potassium-phosphorus combinations in the second year of cultivation.

\begin{tabular}{|c|c|c|c|c|c|c|c|}
\hline \multirow{3}{*}{ Source of variation } & \multicolumn{7}{|c|}{ F test } \\
\hline & $\mathrm{Chla}$ & $C h l b$ & Car & Fo & $\mathrm{Fm}$ & Fv & $\mathrm{Fv} / \mathrm{Fm}$ \\
\hline & \multicolumn{7}{|c|}{ First production cycle } \\
\hline Saline levels (SL) & $* *$ & ** & * & $* *$ & * & * & $* *$ \\
\hline Fertilization combinations (FC) & ** & ** & ns & ** & ns & ns & ns \\
\hline Interaction $(\mathrm{SL} \times \mathrm{FC})$ & ** & ** & ns & ** & ns & ns & ns \\
\hline Blocks & ns & ns & ns & ns & ns & ns & ns \\
\hline \multirow[t]{2}{*}{ CV (\%) } & 15.58 & 33.32 & 25.15 & 4.85 & 4.80 & 7.63 & 3.61 \\
\hline & \multicolumn{7}{|c|}{ Second production cycle } \\
\hline Saline levels (SL) & ** & ** & ns & ** & ns & * & ns \\
\hline Fertilization combinations (FC) & ** & ** & ns & * & ** & * & ns \\
\hline Interaction (SL × FC) & $\star *$ & $* *$ & ns & $* *$ & $* *$ & * & ns \\
\hline Blocks & ns & ns & ns & ns & ns & ns & ns \\
\hline CV (\%) & 14.78 & 25.53 & 20.49 & 14.69 & 7.95 & 12.53 & 7.77 \\
\hline
\end{tabular}

$\mathrm{DF}=$ degree of freedom, $\mathrm{CV}=$ coefficient of variation, ${ }^{\text {ns }}$, "and * denote not significant, significant at $\mathrm{p}<0.05$ and significant at $p<0.01$, respectively.
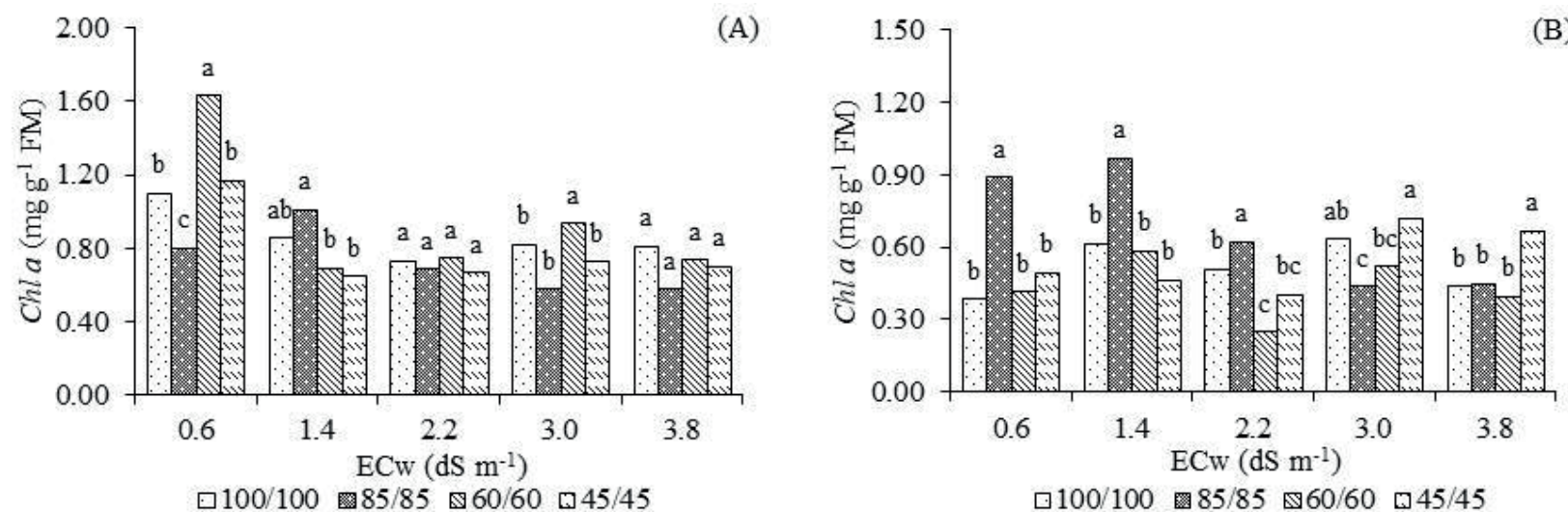

Figure 1. Chlorophyll a content ( $\mathrm{Chl}$ a) of West Indian cherry cv. BRS Jaburu, as a function of the interaction between the electrical conductivity of irrigation water - ECW and different combinations of potassium/phosphorus $\left(\mathrm{K}_{2} \mathrm{O} / \mathrm{P}_{2} \mathrm{O}_{5}\right)$ in the first $(\mathrm{A})$ and the second $(\mathrm{B})$ production cycles. Means followed by different letters indicate a significant difference between treatments by the Tukey test $(p<0.05)$. 
In a comparison of $\mathrm{Chl}$ a contents between the firstand second productioncycles, it was verified that, in general, chlorophyll a synthesis was stimulated when plants were fertilized with $60 / 60$ and $85 / 85 \%$ of the $\mathrm{K}_{2} \mathrm{O}$ / $\mathrm{P}_{2} \mathrm{O}_{5}$ recommendation in the first and second production cycles, respectively. Probably, the existence of interactions between salinity and nutrients such as potassium and phosphorous is an indication that the optimal dose to mitigate salt stress depends on salinity in the root zone of plants and the source used in fertilization (M. L. S. Silva \& Trevizam, 2015). In addition, during the second year of cultivation, there was an intensification of stress due to the progressive accumulation of salts in the soil, and the increase in the amounts of nutrients supplied to the plants from $45 / 45$ to $85 / 85 \%$ under moderate salinity levels (0.6, 1.4 and 2.2 dS $\mathrm{m}^{-1}$ ) proved to be positive because one of the main factors responsible for the absorption of ions by plants is their concentration in the soil solution and the concentration of elements that compete for the adsorption sites.

In the second cycle, the combination of $45 / 45 \%$ of $\mathrm{K}_{2} \mathrm{O}_{2} \mathrm{P}_{2} \mathrm{O}_{5}$ promoted an increase in chlorophyll a contents when plants were grown under water salinity of 3.0 and $3.8 \mathrm{dS} \mathrm{m}^{-1}$. Thus, it is clear that, under high salinity levels, the supply of $45 / 45 \%$ of $\mathrm{K}_{2} \mathrm{O} / \mathrm{P}_{2} \mathrm{O}_{5}$ had mitigating action on chlorophyll a synthesis, possibly because the increase in the supply of mineral fertilizers contributes to the increase in soil $E C$, given their salt indices, especially that of potassium chloride, compromising chlorophyll biosynthesis by crops. This situation has been observed in cowpea (Prazeres et al., 2015), colored cotton (A. R. Silva et al., 2017), and West Indian cherry (Dias et al., 2019) under water salinity conditions.

Regarding chlorophyll $b(C h / b)$ contents in West Indian cherry plants in the first cycle, the means comparison test (Figure 2A) showed a significant difference between the fertilization combinations for plants irrigated using water with electrical conductivities of 1.4, 3.0 and 3.8 $\mathrm{dS} \mathrm{m}^{-1}$. In plants irrigated with water of $1.4 \mathrm{dS} \mathrm{m}^{-1}$, the highest content of $\mathrm{Chl} b\left(0.443 \mathrm{mg} \mathrm{g}^{-1} \mathrm{FM}\right)$ was obtained under fertilization with $85 / 85 \%$ of the $\mathrm{K}_{2} \mathrm{O} / \mathrm{P}_{2} \mathrm{O}_{5}$ recommendation; however, it did not differ from the content obtained in plants that received the combinations of $100 / 100 \%$ and $60 / 60 \% \mathrm{~K}_{2} \mathrm{O} / \mathrm{P}_{2} \mathrm{O}_{5}$. When using the water salinity levels of 3.0 and $3.8 \mathrm{dS} \mathrm{m}^{-1}$ (Figure 2A), the highest chlorophyll $b$ contents (0.509 and $0.482 \mathrm{mg} \mathrm{g}^{-1} \mathrm{FM}$ ) were obtained when plants were fertilized with the combination of $60 / 60 \%$ of $\mathrm{K}_{2} \mathrm{O} / \mathrm{P}_{2} \mathrm{O}_{5}$.

In the second cycle, there was a significant difference between the different combinations of fertilization in the $\mathrm{Ch} / \mathrm{b}$ of West Indian cherry plants (Figure 2B) when irrigated using water with salinities of $0.6,1.4$, and 2.2 $\mathrm{dS} \mathrm{m}^{-1}$. In plants grown under ECw values of 0.6 and $1.4 \mathrm{dS} \mathrm{m}^{-1}$, the highest contents of $\mathrm{Chl} b$ were obtained with the combination of fertilization with $85 / 85 \%$ of $\mathrm{K}_{2} \mathrm{O} / \mathrm{P}_{2} \mathrm{O}_{5}$. While in plants irrigated with ECw 2.2 plants fertilized with 100/100\% combination had significantly higher values of $C h l b$ in relation to other combinations. When plants were grown under

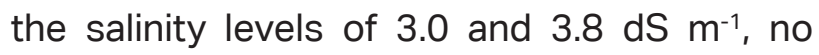
statistical differences were detected between the combinations of $\mathrm{K}_{2} \mathrm{O} / \mathrm{P}_{2} \mathrm{O}_{5}$ (Figure 2B). In the second production cycle, the contents of $C h l b$ were lower than those observed in the first cycle, suggesting that the increase in the combined supply of these nutrients did not mitigate the stress caused by high salinity on the chlorophyll $b$ content of West Indian cherry, possibly due to the intensification of stress caused by the time of exposure of the crop and the salt indices of $\mathrm{KCl}$ and MAP, corresponding to 115 and 30 , respectively. In addition, the 
greater reduction in $\mathrm{Chl} b$ contents may also be related to inhibition of the synthesis of 5-aminolevulinic acid, a chlorophyll precursor molecule, and/or increase in the activity of chlorophyllase enzyme, which degrades chlorophyll (Taiz, Zeiger, Moller, \& Murphy, 2017); the first step in chlorophyll $b$ degradation is its conversion into chlorophyll a (Gomes, Pestana, Santa-Catarina, Hauser-Davis, \& Suzuki, 2017).

Increments in chlorophyll $b$ contents under adverse conditions possibly indicate the activation of a mechanism to protect the photosynthetic apparatus and appear to be a direct implication of the development of chloroplasts, through the expansion in the number of thylakoids or even the increase in the number of chloroplasts (Mendes, Willadino, Cunha, Oliveira, \& Camara, 2011; Silva et al., 2016). Likewise, reductions in chlorophyll synthesis, because of the accumulation of salts in plant tissues, should not be interpreted only from the point of view of the deleterious effects inherent to this stress on plant metabolism. This reduction can be understood as a response of acclimation to the action of stressful agents, expressed by plants, in an attempt to conserve energy and, consequently, capture less light energy, thus avoiding possible photooxidative stresses (Tabot \& Adams, 2013; A. R. A. Silva et al., 2016).

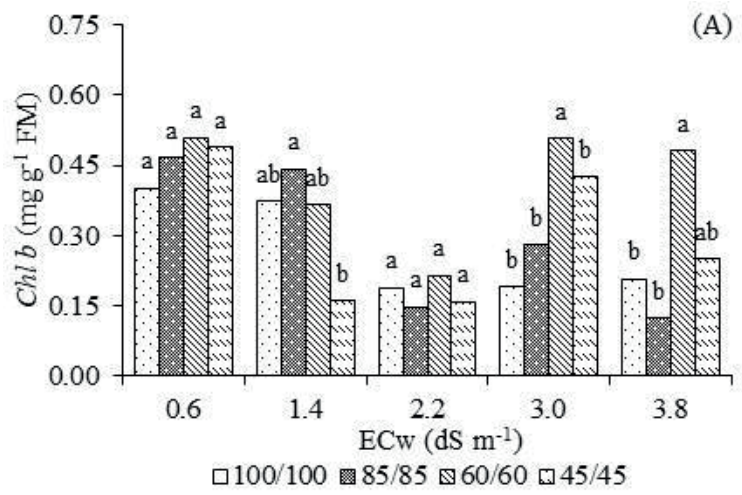

$\square 100 / 100 \backsim 85 / 85 \otimes 60 / 60 \square 45 / 45$

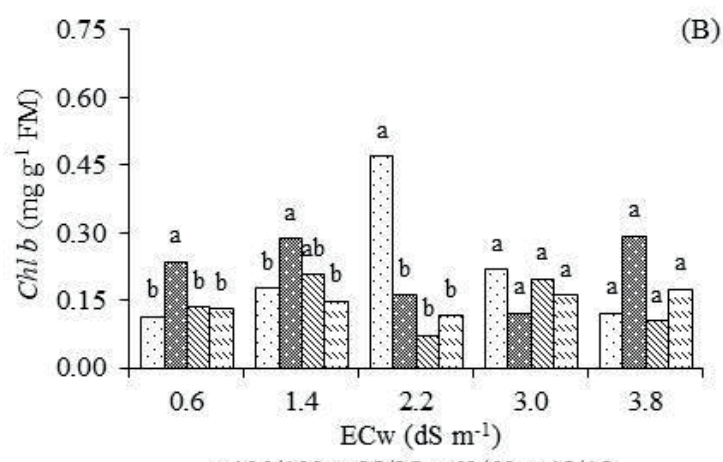

$\square 100 / 100 \rrbracket 85 / 85 \otimes 60 / 60 \square 45 / 45$

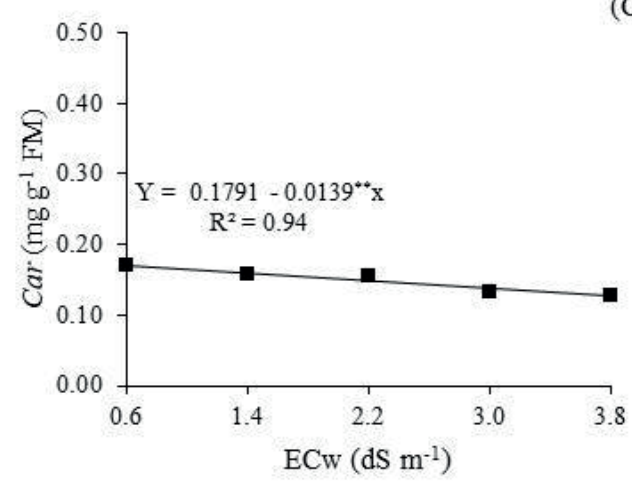

Figure 2. Chlorophyll $b$ content $(\mathrm{Ch} / \mathrm{b}$ ) of West Indian cherry cv. BRS 366 Jaburu as a function of the interaction between the electrical conductivity of irrigation water - ECW and different combinations of potassium/phosphorus $-\mathrm{K}_{2} \mathrm{O} / \mathrm{P}_{2} \mathrm{O}_{5}$ in the first (A) and the second (B) production cycles and carotenoid content (C) as a function of $E C W$, in the first production cycle. Means followed by different letters indicate a significant difference between treatments by the Tukey test $(p<0.05)$. ${ }^{* *}$ denote significant at $p<0.01$. 
The increase in ECw levels caused a linear reduction in the carotenoid content of $7.76 \%$ per unit increment in $\mathrm{ECW}$, that is, plants irrigated with ECw of $3.8 \mathrm{dS} \mathrm{m}^{-1}$ had a reduction Car synthesis of $26.05 \%$ compared to those that received the water of lowest salinity level (Figure 2C). These results may be related to the fact that salt stress reduces the production of photosynthetic pigments to induce the degradation of $\beta$-carotene, which causes a reduction in the content of carotenoids, which are integrated components of the thylakoid membranes, acting in the absorption and transfer of light to chlorophyll (Gomes, Suzuki, Cunha, \& Tullii, 2011; A. R. A. Silva et al., 2016), in addition to protecting chlorophyll from photooxidation (Taiz et al., 2017). Corroborating these results, Dias et al. (2019) found a reduction of $57.2 \%$ in the leaf content of carotenoids as water salinity increased from 0.8 to $3.0 \mathrm{dS} \mathrm{m}^{-1}$ in West Indian cherry cv. BRS 366 Jaburu. Sousa, Gheyi, Brito, Silva and Lima (2017), in a study with citrus under irrigation with saline water, found a

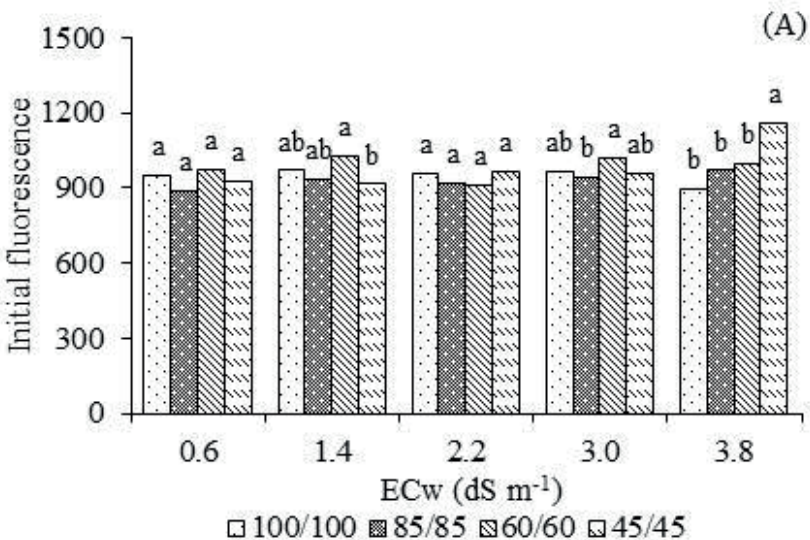

reduction of $38.81 \%$ in carotenoid contents as salinity levels increased from 0.6 to $3.0 \mathrm{dS} \mathrm{m}^{-1}$.

Analysis of the simple effect of $\mathrm{K}_{2} \mathrm{O}$ / $\mathrm{P}_{2} \mathrm{O}_{5}$ fertilization combinations at each salinity level in the first cycle for initial fluorescence (Figure 3A) showed that plants irrigated with ECw values of $1.4,3.0$, and $3.8 \mathrm{dS} \mathrm{m}^{-1}$ were significantly influenced by the $\mathrm{K}_{2} \mathrm{O}$ / $\mathrm{P}_{2} \mathrm{O}_{5}$ fertilization combinations. When plants were grown under an ECw of $1.4 \mathrm{dS} \mathrm{m}^{-1}$ and $60 / 60 \%$ of $\mathrm{K}_{2} \mathrm{O}_{\mathrm{P}} \mathrm{P}_{2} \mathrm{O}_{5}$, they obtained the highest Fo (1022.33), but there was no significant difference from those fertilized with 100/100 and $85 / 85 \%$ of $\mathrm{K}_{2} \mathrm{O} / \mathrm{P}_{2} \mathrm{O}_{5}$. When water with an ECw of $3.0 \mathrm{dS} \mathrm{m}^{-1}$ was used, the highest Fo (1014.66) was obtained in plants that received the $\mathrm{K}_{2} \mathrm{O} / \mathrm{P}_{2} \mathrm{O}_{5}$ combination of $60 / 60 \%$, but they did not differ significantly from those fertilized with $100 / 100$ and $45 / 45 \%$ of $\mathrm{K}_{2} \mathrm{O} / \mathrm{P}_{2} \mathrm{O}_{5}$. In plants irrigated with an ECw of $3.8 \mathrm{dS} \mathrm{m}^{-1}$, the highest initial fluorescence (1159.0) was obtained with the combination of fertilization with $45 / 45 \%$ of $\mathrm{K}_{2} \mathrm{O} / \mathrm{P}_{2} \mathrm{O}_{5}$, which was statistically superior to the other combinations.

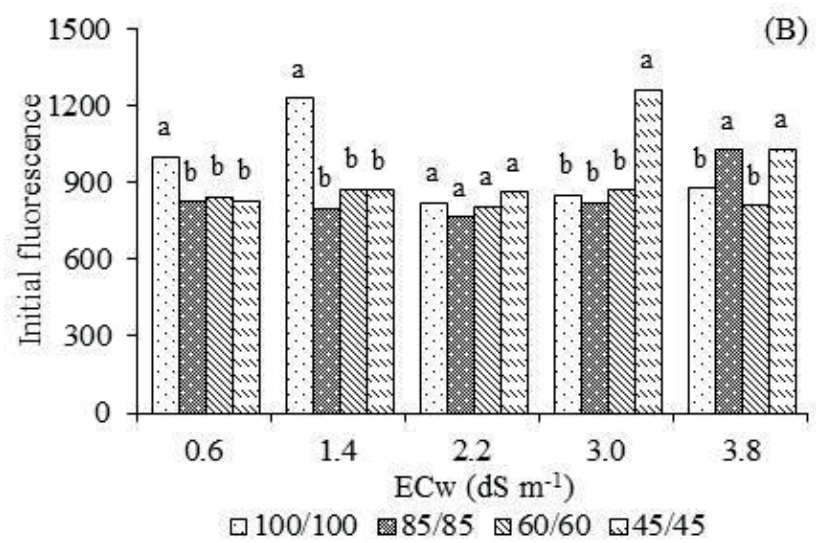

Figure 3. Initial fluorescence of West Indian cherry cv. BRS Jaburu, as a function of the interaction between the electrical conductivity of irrigation water - ECw and different combinations of potassium/phosphorus $\left(\mathrm{K}_{2} \mathrm{O} / \mathrm{P}_{2} \mathrm{O}_{5}\right)$ in the first $(\mathrm{A})$ and the second $(\mathrm{B})$ production cycles. Means followed by different letters indicate a significant difference between treatments by the Tukey test $(p<0.05)$. 
In the second cycle, the initial fluorescence of West Indian cherry was also influenced by the different combinations of potassium/phosphorus fertilization when plants were irrigated with ECw values of 0.6 , 1.4, 3.0, and $3.8 \mathrm{dS} \mathrm{m}^{-1}$ (Figure 3B). Through the unfolding of the interaction, it can be seen that, when plants were irrigated using waters with $\mathrm{ECw}$ values of 0.6 and $1.4 \mathrm{dS}^{-1}$, the highest values of Fo (1002.66 and 1231.66, respectively) were obtained in those under fertilization with $100 / 100 \%$ of $\mathrm{K}_{2} \mathrm{O} / \mathrm{P}_{2} \mathrm{O}_{5}$, differing significantly from those cultivated under 85/85, 60/60 and 45/45\% $\mathrm{K}_{2} \mathrm{O}_{2} \mathrm{P}_{2} \mathrm{O}_{5}$. When plants were irrigated with water of 3.0 and $3.8 \mathrm{dS} \mathrm{m}^{-1}$, fertilization with $45 / 45 \%$ of $\mathrm{K}_{2} \mathrm{O} /$ $\mathrm{P}_{2} \mathrm{O}_{5}$ promoted the highest initial fluorescence. On the other hand, when using an ECw of $3.0 \mathrm{dS}$ $\mathrm{m}^{-1}$, plants that were fertilized with $45 / 45 \%$ had the statistically higher Fo compared to those that were under the combinations of $100 / 100$, $85 / 85$, and $60 / 60 \%$ of $\mathrm{K}_{2} \mathrm{O}_{2} \mathrm{P}_{2} \mathrm{O}_{5}$. While under $\mathrm{ECw}=3.8$ it differed only from plants under combination of $100 / 100$ and $60 / 60 \%$.

For Fo, a similar behavior was observed in both production cycles (Figure 3). In both cycles of cultivation, the increase in water salinity and the combination of fertilization with $45 / 45 \%$ of $\mathrm{K}_{2} \mathrm{O}_{2} \mathrm{P}_{2} \mathrm{O}_{5}$ promoted an increase in initial fluorescence. An increase in Fo is indicative of damage to the photosynthetic apparatus since this variable indicates the loss of light energy, a situation that occurs in a state of oxidation of quinone (primary electron receptor) in the reaction center (P680), hampering the energy transfer of photosystem
II (PSII) (L. A. Silva et al., 2014). Thus, it is possible to affirm that combined fertilization with $\mathrm{K}_{2} \mathrm{O}_{2} \mathrm{P}_{2} \mathrm{O}_{5}$ favors the energy balance of photosynthetic processes, inducing the reduction of the initial fluorescence of West Indian cherry plants under conditions of salt stress.

Regarding the maximum fluorescence of West Indian cherry plants in the first production cycle, a quadratic fit can be observed through the regression equation, with a maximum estimated value for $\mathrm{Fm}$ of 3745.76 obtained in plants cultivated under a water salinity of $2.6 \mathrm{dS} \mathrm{m}^{-1}$ (Figure 4A). The excess of salts in water and/or soil causes damage to the photosynthetic apparatus and the metabolic processes of plants because the contents of pigments that constitute the antenna complex, as observed in this study were reduced (Figures 1 and 2), leading to a deficit in the capture of light energy and negatively affecting the signals of chlorophyll a fluorescence (Bouchenak, Henri, Benrebiha, \& Rey, 2012; Melo, Souza, \& Cunha, 2017). The reduction in $\mathrm{Fm}$ may be related to the photoreduction deficiency in electronacceptor quinone (QA), due to PSII inactivation in the thylakoid membranes from salt stress, which affects the flow of electrons between photosystems as well as photochemical activity in leaves (Lima et al., 2019). In a study with cotton under salt stress, Lima et al. (2019) reported a reduction of $23.76 \%$ in $\mathrm{Fm}$ in plants grown under ECw levels between 9.1 and 5.1 dS $\mathrm{m}^{-1}$. 

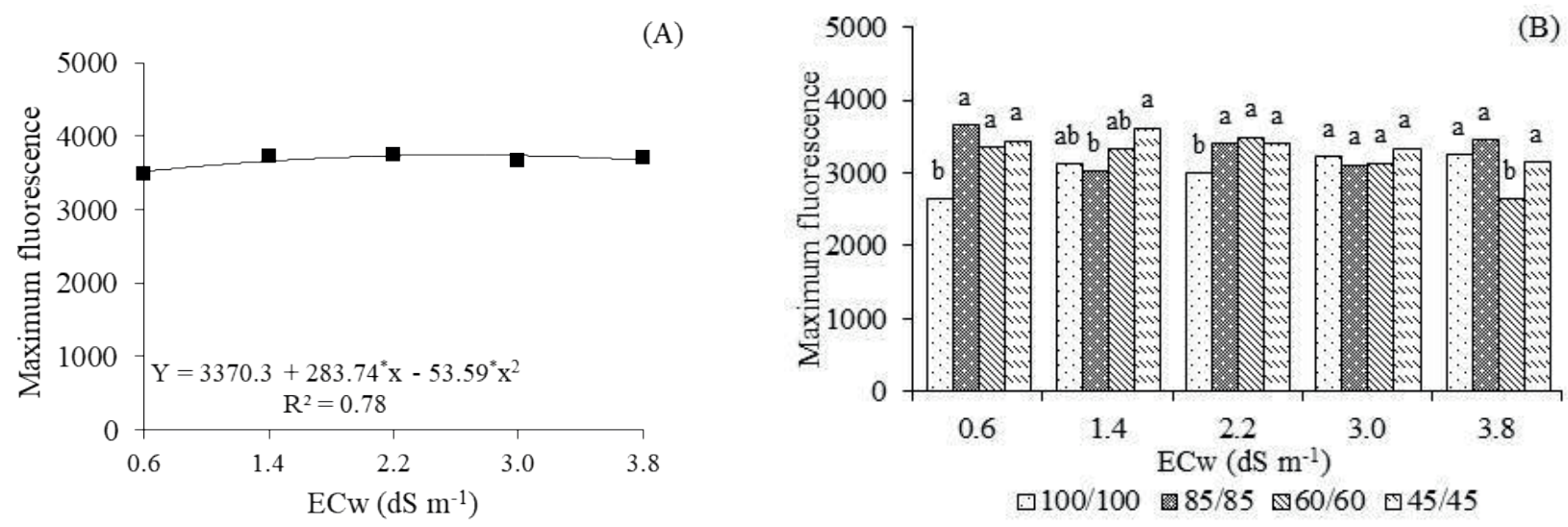

Figure 4. Maximum fluorescence of West Indian cherry cv. BRS 366 Jaburu as a function of the electrical conductivity of irrigation water (ECW) in the first production cycle $(A)$ and as a function of the interaction between the electrical conductivity of irrigation water - ECw and different combinations of potassium/phosphorus $\left(\mathrm{K}_{2} \mathrm{O} / \mathrm{P}_{2} \mathrm{O}_{5}\right)$ in the second production cycle (B). Means followed by different letters indicate a significant difference between treatments by the Tukey test $(p<0.05)$. The * denote significant at $p<0.05$.

According to the means comparison test (Figure 4B), the different combinations of potassium and phosphorus fertilization significantly affected the maximum fluorescence of West Indian cherry in the second production cycle. When West Indian cherry plants were grown under ECw values of 0.6 and $2.2 \mathrm{dS} \mathrm{m}^{-1}$, the lowest values of Fm (2651.66 and 3000.33, respectively) were obtained with the combination of $100 / 100 \%$ of $\mathrm{K}_{2} \mathrm{O} / \mathrm{P}_{2} \mathrm{O}_{5}$, which differed statically from the other combinations which did not differ from one another. When plants were cultivated with an ECw of $1.4 \mathrm{dS} \mathrm{m}^{-1}$ and fertilization with $45 / 45 \%$ of $\mathrm{K}_{2} \mathrm{O} / \mathrm{P}_{2} \mathrm{O}_{5}$, there was an increase in $\mathrm{Fm}$, with no difference between this and the combinations of $100 / 100$ and $60 / 60 \%$ of the $\mathrm{K}_{2} \mathrm{O} / \mathrm{P}_{2} \mathrm{O}_{5}$ recommendation. An analysis of the effect of fertilization with the different combinations of $\mathrm{K}_{2} \mathrm{O} / \mathrm{P}_{2} \mathrm{O}_{5}$ at the highest salinity level $\left(3.8 \mathrm{dS} \mathrm{m}^{-1}\right)$ showed that plants fertilized with $60 / 60 \%$ of $\mathrm{K}_{2} \mathrm{O}_{2} \mathrm{P}_{2} \mathrm{O}_{5}$ had lower $\mathrm{Fm}$ values compared to those that were subjected to $100 / 100,85 / 85$ and $45 / 45 \%$ of the recommended $\mathrm{K}_{2} \mathrm{O} / \mathrm{P}_{2} \mathrm{O}_{5}$ (Figure 4B).

Maximum fluorescence reflects the plant's ability to transfer energy to the formation of the NADPH reducer, ATP, and reduced ferredoxin, consequently affecting $\mathrm{CO}_{2}$ assimilation in the biochemical phase of photosynthesis (Lima et al., 2019), and increments in Fo values associated with reductions in $\mathrm{Fm}$ values can be interpreted as an indication of damage to the PSII lightharvesting complex (Melo et al., 2017), as observed in the present study.

Maximum fluorescence (Fm) directly influences the variable fluorescence (Fv), which is the potentially active energy in PSII, in such a way that, as observed for Fm, the Fv showed quadratic behavior, with the increase in $\mathrm{ECw}$, reaching its maximum estimated value of 2728.25 when plants were cultivated under $2.7 \mathrm{dS} \mathrm{m}^{-1}$. From this ECw level, there was a decrease in $\mathrm{Fv}$ in the evaluation performed 
in the first production cycle (Figure 5A). The reduction in chlorophyll a fluorescence parameter with increasing salinity is directly related to chlorophyll degradation due to ionic toxicity, and decreases in Fv and Fm result in greater damage to the photosynthetic apparatus caused by the water deficit from high salinity levels (Melo et al., 2017).
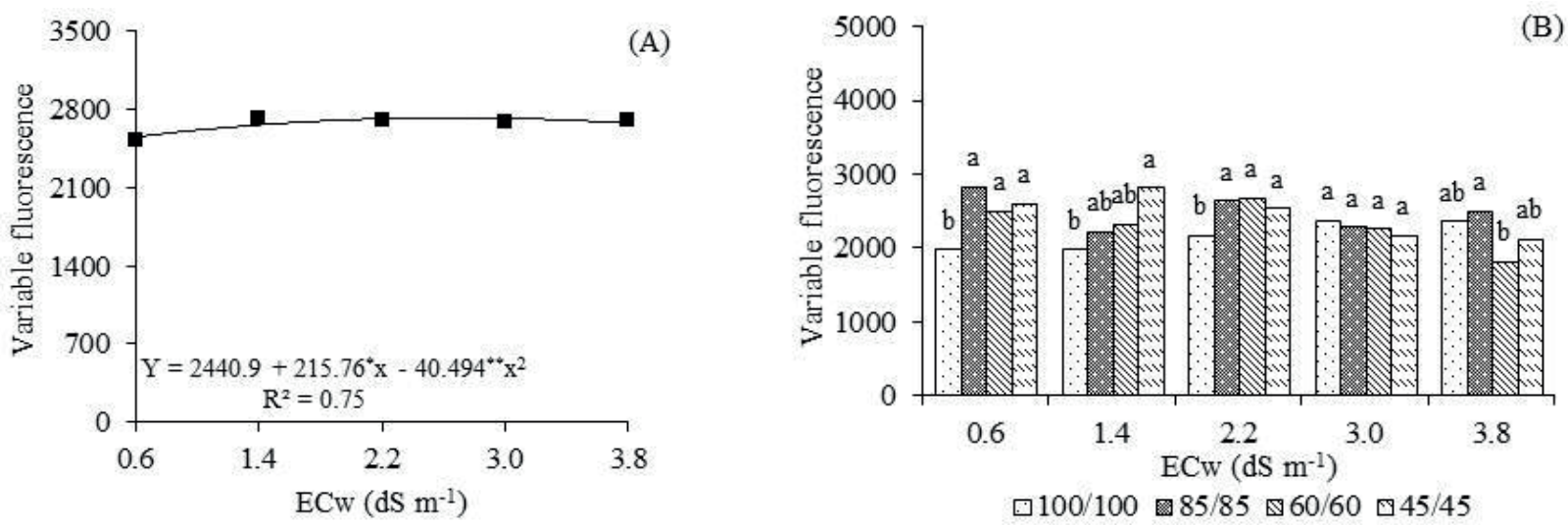

Figure 5. Variable fluorescence of West Indian cherry cv. BRS 366 Jaburu as a function of the electrical conductivity of irrigation water $(E C w)$ in the first production cycle $(A)$ and as a function of the interaction between the electrical conductivity of irrigation water $(\mathrm{ECW})$ and different combinations of potassium/phosphorus $\left(\mathrm{K}_{2} \mathrm{O} / \mathrm{P}_{2} \mathrm{O}_{5}\right.$ in the second production cycle (B). ${ }^{*}$ and ${ }^{* *}$ denote significant at $p<0.05$ and significant at $p<0.01$, respectively.

Regarding Fv in the second production cycle, plants subjected to potassium/ phosphorus fertilization combinations differed statistically when they were grown under ECw values of $0.6,1.4,2.2$, and $3.8 \mathrm{dS} \mathrm{m}^{-1}$ (Figure $5 \mathrm{~B}$ ). When plants were irrigated with $\mathrm{ECW}$ values of 0.6 and $2.2 \mathrm{dS} \mathrm{m}^{-1}$, there was no significant effect on $\mathrm{Fv}$ between the combinations of fertilization with $85 / 85,60 / 60$, and $45 / 45 \%$ of the recommended $\mathrm{K}_{2} \mathrm{O} / \mathrm{P}_{2} \mathrm{O}_{5}$. On the other hand, West Indian cherry plants irrigated with ECw of $1.4 \mathrm{dS} \mathrm{m}^{-1}$ and fertilized with the combination of $45 / 45 \%$ of $\mathrm{K}_{2} \mathrm{O} / \mathrm{P}_{2} \mathrm{O}_{5}$ obtained the highest Fv (2817.66), which was statistically higher than that of plants cultivated with $100 / 100 \%$ of $\mathrm{K}_{2} \mathrm{O} /$ $\mathrm{P}_{2} \mathrm{O}_{5}$. However, under the high-salinity water (3.8 $\mathrm{dS} \mathrm{m}^{-1}$ ) the supply of $85 / 85 \%$ of $\mathrm{K}_{2} \mathrm{O} / \mathrm{P}_{2} \mathrm{O}_{5}$ promoted higher Fv (2501.66), but these plants differed only from those under fertilization with $60 / 60 \%$ of $\mathrm{K}_{2} \mathrm{O}_{\mathrm{P}} \mathrm{P}_{2} \mathrm{O}_{5}$.

In general, under conditions of high $\mathrm{ECw}$, the combined supply of potassium and phosphorus can attenuate the deleterious effects of salt stress, probably due to their physiological functions. Phosphorous is a key element of the intermediate compounds participating in electron transport and its adequate supply promotes an increase in quantum yields and quantum efficiencies resulting from the increments generated by this element in the absorbed energy flux per reaction center, in the electron transport, in the trapped energy flux per reaction center and the energy dissipation as heat per reaction center (Sayyad-Amin, Jahansooz, Borzouei, \& Ajili, 2016). 
Potassium acts as an enzymatic activator in the ionic absorption process and the osmotic regulation of the plant (Taiz et al., 2017), favoring the absorption of water and nutrients under saline conditions. Its inadequate supply, during the photosynthetic process, can cause a reduction in the consumption of ATP and NADPH produced in the photochemical phase of photosynthesis, due to the insufficient supply of $\mathrm{CO}_{2}$ to be fixed by RuBisCO (ribulose-1,5-bisphosphate carboxylase oxygenate) in the biochemical phase of photosynthesis resulting from the closure of stomata (Schreiner, Lee, \& Skinkis, 2013; Chaves et al., 2016), promoting the synthesis of reactive oxygen species, which damage proteins, pigments, and photosystems, reducing the role of chlorophyll in the photochemical phase of photosynthesis and the availability of substrates for the biochemical phase of photosynthesis (Chaves et al., 2016).

The increase in irrigation water salinity significantly affected the quantum efficiency of photosystem II (Fv/Fm) only in the evaluation performedinthefirstproductioncycle, standing out as a possible acclimation response of plants as a function of the combined supply of potassium/phosphorus (Figure 6), given the decreases in chlorophyll $a$ and $b$ contents (respectively, Figures 1B and 2B) observed in the present study in the second production cycle, corroborating the theory presented by A. R. A. Silva et al. (2016), according to which reductions in leaf contents of chlorophyll in response to salt stress occur as an acclimation response, adopted by some plants to capture less light energy, thus avoiding photooxidative stresses resulting from the action of ROS and preserving the photosynthetic apparatus.

According to the regression equation (Figure 6), there was a quadratic response of Fv/Fm as a function of the salinity increment, with a maximum $\mathrm{Fv} / \mathrm{Fm}$ value of 0.75 in plants subjected to an ECw of $2.7 \mathrm{dS} \mathrm{m}^{-1}$ and reduction from this level. Quantum efficiency expresses the light absorbed by photosystem II and serves as an indicator of the photosynthetic performance of plants (Taiz et al., 2017). A reduction in the quantum efficiency of photosystem II indicates changes in the photosynthetic system caused by environmental and biotic stresses. This inhibition detected in plants cultivated with saline water indicates the occurrence of photoinhibition damage to PSIl reaction centers, which promotes the formation of reactive oxygen species (Lima et al., 2019). 


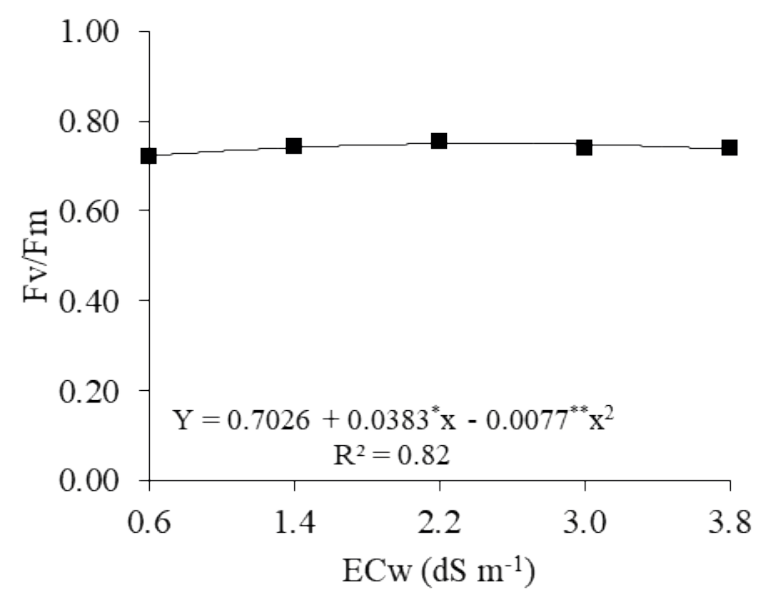

Figure 6. Quantum efficiency of photosystem II (Fv/Fm) of West Indian cherry cv. BRS 366 Jaburu, as a function of the electrical conductivity of irrigation water $(E C w)$ in the first production cycle. " and "* denote significant at $p<0.05$ and significant at $p<0.01$, respectively.

\section{Conclusions}

Irrigation with saline waters hampers the biosynthesis of chloroplast pigments and the photochemical efficiency of West Indian cherry cv. BRS 366 Jaburu in the second year of cultivation.

Water salinity values from $2.6 \mathrm{dS} \mathrm{m}^{-1}$ reduce the maximum fluorescence, variable fluorescence, and quantum efficiency of photosystem II of West Indian cherry plants cv. BRS 366 Jaburu.

Fertilization with $60 / 60$ and $85 / 85 \%$ of the $\mathrm{K}_{2} \mathrm{O}_{2} \mathrm{P}_{2} \mathrm{O}_{5}$ recommendation promotes an increase in chlorophyll $a$ and $b$ contents of West Indian cherry, respectively, in the first and second production cycles of the second year of cultivation.

Supply of $85 / 85 \%$ of the $\mathrm{K}_{2} \mathrm{O} / \mathrm{P}_{2} \mathrm{O}_{5}$ recommendation promotes an increase in the maximum fluorescence and variable fluorescence in plants subjected to water salinity levels of $0.6,2.2$, and $3.8 \mathrm{dS} \mathrm{m}^{-1}$ in the second cycle and reduces the initial fluorescence, regardless of the salinity level, in the first and second production cycles of West Indian cherry.

\section{References}

Andrade, W. P., Jr., Pereira, F. H. F., Fernandes, O. B., Queiroga, R. C. F., \& Queiroga, F. M. (2011). Efeito do nitrato de potássio na redução do estresse salino no meloeiro. Revista Caatinga, 24(3), 110-119.

Arnon, D. I. (1949). Copper enzymes in isolated cloroplasts: polyphenoloxidases in Beta vulgaris. Plant Physiology, 24(1), 1-15. doi: 10.1104/pp.24.1.1 
Bouchenak, F., Henri, P., Benrebiha, F. Z., \& Rey, P. (2012). Differential responses to salinity of two Atriplex halimus populations in relation to organic solutes and antioxidant systems involving thiol reductases. Journal of Plant Physiology, 169(15), 14451453. doi: 10.1016/j.jplph.2012.06.009

Calgaro, M., \& Braga, M. B. (2012). A cultura da acerola (3a ed.). Brasília, DF: Empresa Brasileira de Pesquisa Agropecuária.

Cavalcanti, F. J. A. (2008). Recomendações de adubação para o Estado de Pernambuco: 2. aproximação. (2a ed. rev.). Recife, PE: Instituto Agronômico de Pernambuco (IPA).

Chaves, A. R. M., Silva, D. J., Aidar, S. T., Santos, L. M., Prado, K. A. C., \& Costa, B. R. S. (2016). Potassium doses on the ecophysiological characteristics of 'Syrah' grapevine grown at São Francisco River Valley, Brazil. Comunicata Scientiae, 7(3), 362-371. doi: 10.14295/cs.v7i3.1764

Dias, A. S., Lima, G. S., Pinheiro, F. W. A., Gheyi, H. R., \& Soares, L. A. A. (2019). Gas exchanges, quantum yield and photosynthetic pigments of West Indian cherry under salt stress and potassium fertilization. Revista Caatinga, 32(2), 429-439. doi: 10.1590/1983-21252019v32n216rc

Diniz, G. L., Sales, G. N., Sousa, V. F. O., Andrade, F. H. A., Silva, S. S., \& Nobre, R. G. (2018). Produção de mudas de mamoeiro sob salinidade da água irrigação e adubação fosfatada. Revista de Ciências Agrárias, 4(1), 218-228. doi: 10.19084/RCA17067

Ferreira, D. F. (2011). Sisvar: a computer statistical analysis system. Ciência e Agrotecnologia, 35(6), 1039-1042. doi: 10.1590/S1413-70542011000600001

Furlaneto, F. P. B., \& Nasser, M. D. (2015). Panorama da cultura da acerola no estado de São Paulo. Pesquisa \& Tecnologia, 12(1), 1-6.
Gomes, M. A. C., Pestana, I. A., Santa-Catarina, C., Hauser-Davis, R. A., \& Suzuki, M. S. (2017). Salinity effects on photosynthetic pigments, proline, biomass and nitric oxide in Salvinia auriculata Aubl. Acta Limnologica Brasiliensia, 29(9), 1-13. doi: $10.1590 / s 2179-975 \times 4716$

Gomes, M. A. C., Suzuki, M. S., Cunha, M., \& Tullii, C. F. da. (2011). Effect of salt stress on nutrient concentration, photosynthetic pigments, proline and foliar morphology of Salvinia auriculata Aubl. Acta Limnologica Brasiliensia, 23(2), 164-176. doi: 10.1590/ S2179-975X2011000200007

Guimarães, S. O., Costa, A. A., Vasconcelos, F. das C. Jr., Silva, E. M. da, Sales, D. C., Araújo, L. M. de Jr., \& Souza, S. G. de. (2016). Projeções de mudanças climáticas sobre o nordeste brasileiro dos modelos do CMIP5 e do CORDEX. Revista Brasileira de Meteorologia, 31(3), 337-365. doi: 10.1590/0102-778631320150150

Heidari, M., \& Jamshid, P. (2010). Interaction between salinity and potassium on grain yield, carbohydrate content and nutrient uptake in pearl millet. ARPN Journal of Agricultural and Biological Science, 5(6), 39-46.

Lima, G. S., Dias, A. S., Soares, L. A. A., Gheyi, H. R., Nobre, R. G., \& Silva, A. A. R. (2019). Eficiência fotoquímica, partição de fotoassimilados e produção do algodoeiro sob estresse salino e adubação nitrogenada. Revista de Ciências Agrárias, 42(1), 214-225. doi: 10.19084/RCA18123

Melo, H. F., Souza, E. R., \& Cunha, J. C. (2017). Fluorescence of chlorophyll a and photosynthetic pigments in Atriplex nummularia under abiotic stresses. Revista Brasileira de Engenharia Agrícola e Ambiental, 21(4), 232-237. doi: 10.1590/1807-1929/agriambi.v21n4 p232-237 
Mendes, B. S. S., Willadino, L., Cunha, P. C., Oliveira, R. A., Fo., \& Camara, T. R. (2011). Mecanismos fisiológicos e bioquímicos do abacaxi ornamental sob estresse salino. Revista Caatinga, 24(3), 71-77.

Musser, R. S. (1995). Tratos culturais na cultura da acerola. In Acerola no Brasil: produção e mercado (pp. 47-52). Vitória da Conquista, BA: DFZ/UESB.

Prazeres, S. S., Lacerda, C. F. de, Barbosa, F. E. L., Amorim, A. V., Araújo, I. C. S., \& Cavalcante, L. F. (2015). Crescimento e trocas gasosas de plantas de feijão-caupi sob irrigação salina e doses de potássio. Revista Agro@mbiente, 9(2), 111-118. doi: 10.18227/1982-8470ragro.v9i2.2161

Sá, F. V. da S., Gheyi, H. R., Lima, G. S. de, Moreira, R. C. L., Dias, A. S., Silva, L. de A.,... Ferreira, M. Neto. (2019a). Physiological indices of West Indian cherry (Malpighia emarginata) irrigated with saline water under nitrogen and phosphorus doses. Australian Journal of Crop Science, 13(7), 1141-1148. doi: 10.21475/ajcs.19.13.07.p1650

Sá, F. V., Gheyi, H. R., Lima, G. S., Paiva, E. P., Silva, L. A., Moreira, R. C. L., \& Dias, A. S. (2019b). Ecophysiology of West Indian cherry irrigated with saline water under phosphorus and nitrogen doses. Bioscience Journal, 35(1), 211-221. doi: 10.14393/BJ-v35n1a2019-41742

Sayyad-Amin, P., Jahansooz, M. R., Borzouei, A., \& Ajili, F. (2016). Changes in photosynthetic pigments and chlorophyll-a fluorescence attributes of sweet-forage and grain sorghum cultivars under salt stress. Journal of Biological Physics, 42(4), 601620. doi: 10.1007/s10867-016-9428-1

Schreiner, R. P., Lee, J., \& Skinkis, P. A. (2013). N, P, and K supply to Pinot noir grapevines: impact on vine nutrient status, growth, physiology, and yield. American Journal of
Enology and Viticulture, 64(1), 26-38. doi: 10.5344/ajev.2012.12064

Silva, A. R., Lima, G. S., Azevedo, C. A. V., Soares, L. A. A., Gheyi, H. R., \& Oliveira, R. C. (2017). Potassium fertilization in the cultivation of colored cotton irrigated with saline water. Revista Brasileira de Engenharia Agrícola e Ambiental, 21(9), 628-633. doi: 10.1590/1807-1929/agriambi.v21n9 p628-633

Silva, A. R. A., Bezerra, F. M. L., Lacerda, C. F., Sousa, C. H. C., \& Chagas, K. L. (2016). Pigmentos fotossintéticos e potencial hídrico foliar em plantas jovens de coqueiro sob estresses hídrico e salino. Revista Agro@mbiente, 10(4), 317325. doi: 10.18227/1982-8470ragro. v10i4.3650

Silva, E. M., Gheyi, H. R., Nobre, R. G., Barbosa, J. L., \& Souza, C. M. A. (2019). Morphology and production of West Indian cherry irrigated with saline waters under combinations of nitrogen-potassium fertilization. Revista Caatinga, 32(4), 1027-1037. doi: 10.1590/1983-21252019v32n419rc

Silva, L. A., Brito, M. E. B., Sá, F. V. S., Moreira, R. C. L., Soares, W. S., Fo., \& Fernandes, P. D. (2014). Mecanismos fisiológicos de percepção do estresse salino de híbridos de porta-enxertos citros em cultivo hidropônico. Revista Brasileira de Engenharia Agrícola e Ambiental, 18(Supl.), 1-7. doi: 10.1590/ 1807-1929/ agriambi.v18nsupps1-s7

Silva, M. L. S., \& Trevizam, A. R. (2015). Interações iônicas e seus efeitos na nutrição das plantas. Informações Agronômicas, 149(1), 10-16.

Sousa, J. R. M., Gheyi, H. R., Brito, M. E. B., Silva, F. A. F. D., \& Lima, G. S. (2017). Dano na membrana celular e pigmentos clorofilianos de citros sob águas 
salinas e adubação nitrogenada. Irriga, 22(2), 353-368. doi: 10.15809/ irriga.2017v22n2p353-368

Tabot, P. T., \& Adams, J. B. (2013). Early responses of Bassia diffusa (Thunb.) Kuntze to submergence for different salinity treatments. South African Journal of Botany, 84(1), 19-29. doi: 10.1016/j. sajb.2012. 10.002
Taibi, K., Taibi, F., Abderrahim, L. A., Ennajah, A., Belkhodja, M., \& Mulet, J. M. (2016). Effect of salt stress on growth, chlorophyll content, lipid peroxidation and antioxidant defence systems in Phaseolus vulgaris L. South African Journal of Botany, 105(1), 306-312. doi: 10.1016/j.sajb.2016.03.011

Taiz, L., Zeiger, E., Moller, I. M., \& Murphy, A. (2017). Fisiologia e desenvolvimento vegetal (6a ed.). Porto Alegre, RS: Artmed.

Teixeira, P. C., Donagema, G. K., Fontana, A., \& Teixeira, W. G. (2017). Manual de métodos de análise de solo (3a ed.). Brasília, DF: EMBRAPA. 